\section{CA repeat polymorphism at the ASS locus}

\author{
M.A.R.Yuille, R.M.Hampson, R.M.Harris, N.A.Affara, \\ J.R.W.Yates and M.A.Ferguson-Smith \\ Department of Pathology, University of Cambridge, Tennis \\ Court Road, Cambridge CB2 1QP, UK
}

Introduction: We report a polymorphism at a CA repeat in the human argininosuccinate synthetase gene (ASS) which has been mapped to 9q34 (Carritt and Povey, 1979; Su et al., 1984).

Source/Description: Using universal sequencing primer, ASSG1, a EcoRI-PvuII fragment from the 14th intron of ASS (Northrup et al. 1989) in pUC8, was found to contain a dinucleotide repeat: (CA) 16. Flanking primers were designed giving a 132 bp PCR product.

TG primer: 5'GGGAGCTATAAAAATGACCA3'

CA primer: 5'TTAGGTCCGAAAACACAAAG3'

Polymorphism: Ten alleles were detected, designated A1 (121 bp), A2 (131 bp), A3 (133 bp), A4 (135 bp), A5 (137 bp), A6 (139 bp), A7 (141 bp), A8 (143 bp), A9 (145 bp) and A10 (147 bp).

Frequency: From 62 unrelated individuals: $\mathrm{A} 1=0.01 ; \mathrm{A} 2=$ $0.15 ; \mathrm{A} 3=0.26 ; \mathrm{A} 4=0.07 ; \mathrm{A} 5=0.14 ; \mathrm{A} 6=0.02 ; \mathrm{A} 7=$ $0.13 ; \mathrm{A} 8=0.12 ; \mathrm{A} 9=0.08 ; \mathrm{A} 10=0.02$. Of these individuals $64 \%$ were heterozygous.

Mendelian Inheritance: Autosomal co-dominant segregation was observed in 23 families with 203 individuals.

Other Comments: PCR was carried out using a Perkin-Elmer Cetus (Norwalk, CT) DNA Thermal Cycler. Each $10 \mu$ l reaction contained $200 \mathrm{ng}$ genomic DNA, $30 \mathrm{ng}$ of each primer, $0.6 \mathrm{U}$ Taq DNA polymerase, $100 \mu \mathrm{M}$ of each of dATP, dGTP and TTP, $0.4 \mu \mathrm{M}$ dCTP, $25 \mathrm{nCi}$ [alpha 32P]dCTP at $3000 \mathrm{Ci} / \mathrm{mmol}$. Amplification conditions were $98^{\circ} \mathrm{C} / 10 \mathrm{mins}$, then 35 cycles of $94^{\circ} \mathrm{C} / 15$ secs; $51^{\circ} \mathrm{C} / 30$ secs; $72^{\circ} \mathrm{C} / 30$ secs with a final elongation step of $72^{\circ} \mathrm{C} / 10$ mins. A $1.5 \mu \mathrm{l}$ aliquot was electrophoresed on a $6 \%$ polyacrylamide sequencing gel which was fixed, dried and exposed to Fuji RX film. The EMBL Data Library has assigned accession number X53535 to the sequences referred to herein.

Acknowledgements: We thank Dr H. Northrup (Institute for Molecular Genetics, Baylor College of Medicine, Houston, TX) for supplying the probe ASSG1 and Dr S.Chamberlin (St. Mary'S Hospital, London) for advice on PCR. This work was supported by grants from the Imperial Cancer Research Fund and the Medical Research Council.

References: 1) Carritt,B. and Povey,S. (1979). Regional assignment of the loci AK3, ACONs and ASS on human chromosome 9. Cytogen. Cell. Genet. 23, 171-181. 2) Northrup,H., Lathrop,M., Lu,S.-Y., Daiger,S.P., Beaudet,A. and O'Brien,W. (1989) Multilocus linkage analysis with the human argininosuccinate synthetase gene. Genomics 5, 442-445. 3) Su,T.-S., Nussbaum,R.L., Airhart,S., Ledbetter,D.H., Mohandas,T., O'Brien,W.E. and Beaudet,A.L. (1984) Human chromosomal assignments for 14 argininosuccinate synthetase pseudogenes: cloned DNAs as reagents for cytogenetic analysis. Am. J. Hum. Genet. 36, 954-964.

\section{A Taql RFLP in the human ret proto-oncogene}

T.Tahira, M.Shiraishi', Y.Ishizaka, I.Ikeda, R.Sakai, T.Sugimura and M.Nagao*

Carcinogenesis Division and ${ }^{1}$ Oncogene Division, National Cancer Center Research Institute, 1-1, Tsukiji 5-chome,

Chuo-ku, Tokyo 104, Japan

Source/Description: A cDNA clone of ret proto-oncogene (pN6) was isolated from a neuroblastoma cell line, Nagai (1). A 562 bp Sall-BamHI fragment subcloned into Bluescript pKS-M13+ (pN6SB) was used as a probe.

Polymorphism: TaqI identifies a two allele polymorphism with bands at $2.8+1.7 \mathrm{~kb}(\mathrm{~A} 1)$ and $2.6+1.8 \mathrm{~kb}(\mathrm{~A} 2)$. Invariant bands at $0.8 \mathrm{~kb}$ and $0.7 \mathrm{~kb}$ are also present (Fig. 1).

Frequency: Studied in 46 unrelated Japanese individuals:

A1: 0.43

A2: 0.57

Not Polymorphic For: EcoRI, BamHI.

Chromosomal Localization: Human ret proto-oncogene has been mapped to chromosome $10 \mathrm{q} 11.2$ (2).

Mendelian Inheritance: Co-dominant segregation shown in one informative family with 5 individuals (Fig. 2).

Probe Availability: Contact M.Nagao.

Other Comments: This RFLP was observed under normal stringencies.

Acknowledgements: This work was supported by a Grant-in-Aid from the Ministry of Health and Welfare for the Comprehensive 10-year Strategy for Cancer Control, Japan.

References: 1) Tahira, T. et al. (1990) Oncogene 5, 97-102. 2) Ishizaka,Y. et al. (1989) Oncogene 4, 1519-1521.
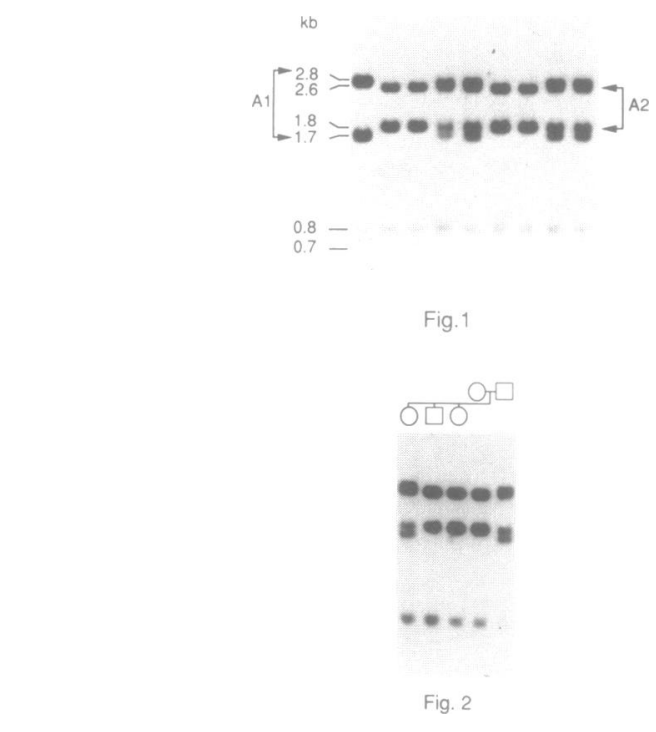

* To whom correspondence should be addressed 